\title{
Mining and Metal Pollution: Assessment of Water Quality in the Tarkwa Mining Area*
}

\author{
${ }^{1}$ A. Ewusi, ${ }^{2}$ B. Y. Apeani, ${ }^{1}$ I. Ahenkorah and ${ }^{3}$ R. S. Nartey \\ ${ }^{1}$ University of Mines and Technology, P.O. Box 237, Tarkwa, Ghana \\ ${ }^{2}$ Technische Universitat, Bergakademie Freiberg, Germany \\ ${ }^{3}$ Radford University College, Accra, Ghana
}

Ewusi, A., Apeani, B. Y., Ahenkorah, I. and Nartey, R. S. (2017), "Mining and Metal Pollution: Assessment of Water Quality in the Tarkwa Mining Area”, Ghana Mining Journal, Vol. 17, No. 2, pp. 17 - 31.

\begin{abstract}
The quality of water in mining communities is uncertain since metals associated with acid mine drainage are known to saturate these waters. Previous studies in Tarkwa, an area noted for gold and manganese extraction, have reported large concentrations of aluminium, arsenic, cadmium, copper, lead, manganese and mercury in water samples. This research aimed at investigating the chemistry of groundwater with special focus on the contamination status of trace elements. It also compared levels of metal concentration with those that were determined in previous research works, to identify changes that might have occurred. Thirty-eight water samples from boreholes, hand-dug wells and streams, within the Tarkwa area were obtained and analysed. Results show that $90 \%$ of water in the area is acidic and Eh was determined to be positive, depicting oxidizing conditions. Mean groundwater temperature was $28.9^{\circ} \mathrm{C}$. Thirty-two samples had either temperature or $\mathrm{pH}$ values falling outside the range recommended by the World Health Organisation (WHO). Thirty samples had at least one metal concentration exceeding the WHO guideline values. Among the list of elements that exceeded the guideline, arsenic, manganese, nitrate, nitrite and iron were the most predominant. The dominant ions in the samples were sodium and bicarbonate. High concentrations of $\mathrm{Fe}$ and $\mathrm{SO}_{4}{ }^{2-}$ in some parts of the study area point to the influence of acid mine drainage (AMD). Comparisons of results of metal concentrations with findings from previous research in the area showed a reduction in concentration. Hydrochemical modelling with PhreeqC attributed this reduction to sorption processes. Comparison of levels of metal concentration in the different water supply facilities (borehole, hand-dug well and stream) showed no significant variations.
\end{abstract}

Keywords: Water Quality, Drinking Water, Hydrochemical Modelling, Heavy Metals

\section{Introduction}

The economic and environmental relevance of groundwater resources makes its study and understanding a vital step towards the management of risks and uncertainties associated with its usage. About 3.5 million people die every year owing to non-potable and inadequate supply of water, occurring predominantly in developing countries (Buxeda et al., 2003). Considering the temperature and climate of Africa and its associated frequent drought, coupled with degradation from landuse such as mining and agriculture, physical and chemical characteristics of aquifer systems and the behaviour of flow are critically important to developing a long term and sustainable water supply function.

Previous studies in the Tarkwa area have reported large amounts of arsenic in ground and surface water, plant, soil and food items, with mining being the main cause (Amasa, 1975; Asante et al., 2007). These reports suggest that sulphide minerals especially arsenopyrite is strongly associated with gold in mining areas (Smedley, 1996). According to Amasa, (1975), concentrations of Arsenic measured in water resources include $1400 \mu \mathrm{g} / \mathrm{L}$ for drinking water and $2250 \mu \mathrm{g} / \mathrm{L}$ for dam water.
Tarkwa is host to two major gold mining and one manganese company as well as registered and unregistered small scale mining companies. Asante et al., (2007) analysed arsenic in the Tarkwa area and concluded that urinary arsenic concentrations ranged between $34 \mu \mathrm{g} / \mathrm{L}$ to $700 \mu \mathrm{g} / \mathrm{L}$ with $58 \%$ of boreholes and $33 \%$ of rivers in the area exceeding the WHO guideline value of $10 \mu \mathrm{g} / \mathrm{L}$.

Mercury (Hg) is used by illegal miners (galamsey) to effectively extract gold from the subsurface. Although its use in small scale mining was a known issue in other countries, it was not until the late 1970s that miners in Ghana began to utilise it in artisanal gold mining. Since then, the mining sector has received great attention from a large number of unskilled small scale miners operating illegally, who out of the difficulty in extracting gold from rocks, turn to the use of mercury in amalgamation (Asante et al., 2007). They use mercury in high quantities, for the amalgamation of an insignificant amount of gold. According to Babut et al., (2003), the ratio of mercury used by miners to gold in Ghana is $4: 1$.

Apart from it being inhaled by gold washers, mercury may also pollute rivers and even find its way into groundwater. Babut et al., (2003) reported mercury concentration in rivers and boreholes to 
range between $0.18 \mu \mathrm{g} / \mathrm{L}$ and $0.76 \mu \mathrm{g} / \mathrm{L}$ and 0.12 $\mu \mathrm{g} / \mathrm{L}$ and $0.27 \mu \mathrm{g} / \mathrm{L}$ respectively.

The primary objective of the study is to investigate the chemistry of groundwater in the Tarkwa area with special focus on the contamination status of trace elements and to compare levels of metal concentration with those which were determined in previous research, so as to identify changes that might have occurred.

\subsection{Location}

Tarkwa area, well noted for the extraction of gold and manganese in Ghana, is located between latitude $4^{\circ} 50^{\prime} \mathrm{N}$ and $5^{\circ} 24^{\prime} \mathrm{N}$ and longitude $1^{\circ} 50^{\prime} \mathrm{W}$ and $2^{\circ} 10^{\prime} \mathrm{W}$. It has a total land area of about $905 \mathrm{~km}^{2}$. Tarkwa (Fig. 1) is the capital of the Tarkwa-Nsuaem municipality (Agyapong and Otoo, 2014).

\subsection{Climate}

The Tarkwa area lies within the south-western equatorial climatic zone with temperatures ranging between $26{ }^{\circ} \mathrm{C}$ and $30{ }^{\circ} \mathrm{C}$. Throughout the year, it records a generally high but less fluctuating humidity, from $70 \%$ to $80 \%$ during both dry and wet seasons. Elevation ranges between $70 \mathrm{~m}$ to $300 \mathrm{~m}$ above mean sea level (Agyapong and Otoo, 2014). It also records one of the highest rainfalls in Ghana with mean annual precipitation of about $1500 \mathrm{~mm}$.

\subsection{Geology}

Tarkwa lies within the Ashanti gold belt of Ghana which occupies the stretch of hills from Konongo in the north-eastern part to Axim in the southwestern part of Ghana. The area is made up of predominantly crystalline rocks of the Birimian and Tarkwaian formations (Kortatsi, 2002). Both formations are folded along axes depicting a northeast trend (Dapaah-Siakwan and GyauBoakye, 2000). In some locations, these two formations are intruded by sills and dykes of igneous rocks (Fig. 2).

The Tarkwaian is a long and narrow syncline trending northeast about $250 \mathrm{~km}$ long and $160 \mathrm{~km}$ wide (Kortatsi, 2002). It overlies the Birimian formation and show characteristics of immature and coarse-grained sedimentary rocks formed from low intensity metamorphism. It is predominantly made up of quartzite, phyllite, sandstone and conglomerate with intrusive igneous rocks contributing to $20 \%$ of its total mass (DapaahSiakwan and Gyau-Boakye, 2000; Kuma and Younger, 2001). The Tarkwaian group can be subdivided into several rock groups namely Huni Sandstone, Tarkwa Phyllite, Banket Series and Kawere Group.

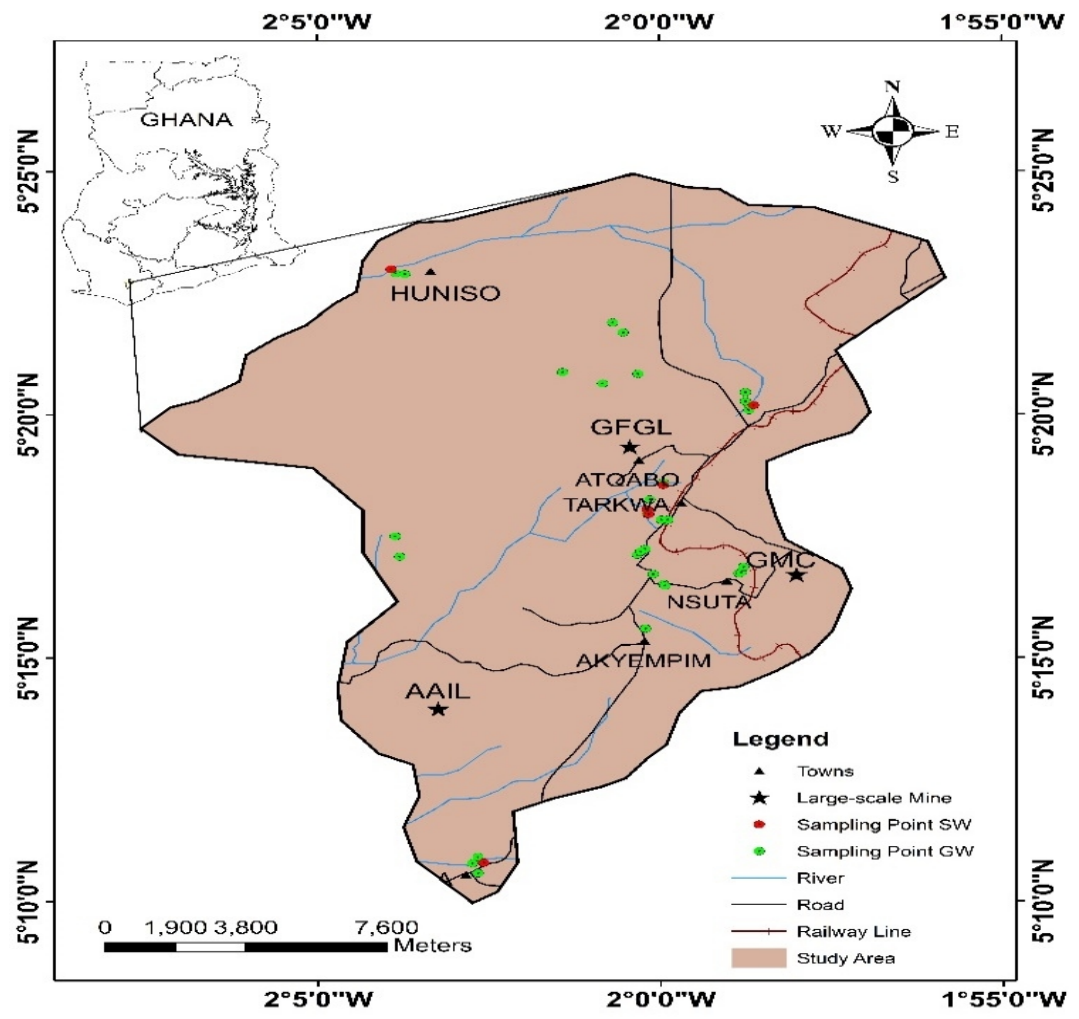

Fig. 1 Map of the Tarkwa Area showing the Sampling Points 
At zones where there is contact between the Tarkwaian and the Birimian formations, there is intense shearing and this hosts significant shearformed gold deposits (Junner et al., 1942).

The Birimian Supergroup is made up of a thick layer of metasedimentary and metavolcanic rocks that are isoclinally folded. The metasedimentary rocks are mainly located at the base of the formation and are composed of slate, schist and phyllite (Dapaah-Siakwan and Gyau-Boakye, 2000). The upper portion of the formation is metavolcanic which consists of rocks of pyroclastic and volcanic origin. Bedded groups of lava and tuff are more dominant in this group. Compared to the Tarkwaian, the Birimian has a higher metal content (Kortatsi, 2002). Fissure and shear zones within the Birimian are often penetrated by veins of quartz consisting of green sericite, carbonate minerals, arsenides and metallic sulphides of $\mathrm{As}, \mathrm{Au}, \mathrm{Cu}, \mathrm{Fe}$, $\mathrm{Zn}, \mathrm{Pb}$ and $\mathrm{Sb}$. In gold exploration, there is often a linear correlation between sulphide minerals and gold and the existence and constituents of the veins of quartz in fissures within the Birimian is no contradiction (Dzigbodi-Adjimah, 1993).

\subsection{Hydrogeology}

In the Tarkwa area, groundwater contributes about $80 \%$ of water supply to meet both domestic and commercial needs of communities. Because of the high dependency on groundwater, water extraction is mostly done through numerous boreholes and hand-dug wells constructed through lithologies of varying thickness (Kortatsi, 2002). Because of the absence of primary porosity among the various rock formations, groundwater occurs as a result of secondary permeability induced by fracturing, jointing, shearing and deep weathering. The area has an undulating topography with numerous low hills recording an average height of about $80 \mathrm{~m}$ and acting as watersheds and groundwater divides (Bhattacharya et al., 2012).

The aquifer in the area ranges from semi-confined to unconfined (Kuma and Younger, 2001). Silt, sand, clay and other combinations form as a result of weathering and are mostly found above transition zones between old weathered rocks and fresh fractures. They tend to have relatively high porosities and storage capacities except for clay and silt which have low permeability.

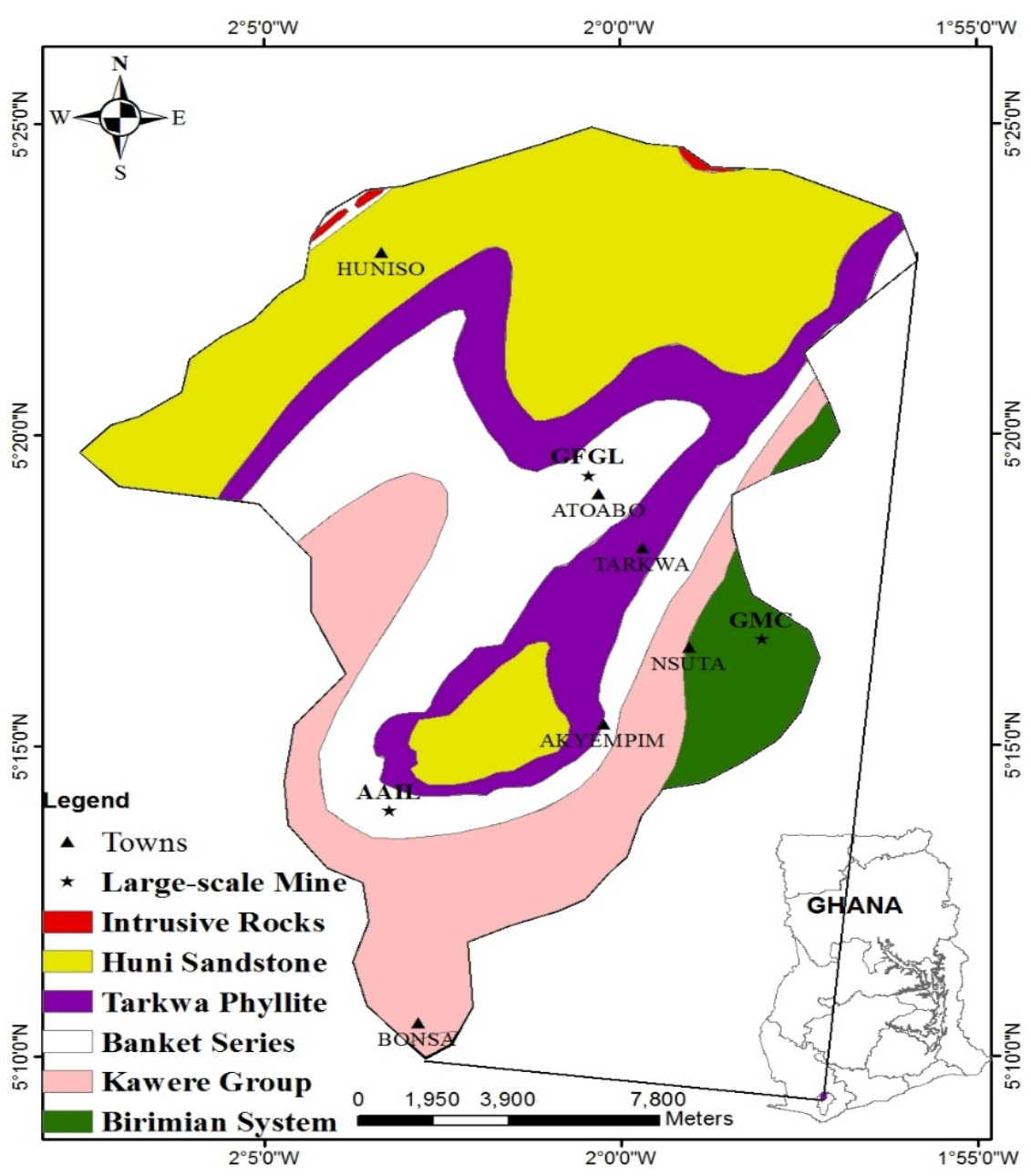

Fig. 2 A Simplified Geological Map of Tarkwa Area (modified after Junner et al., 1942) 
The aquifer below the regolith of sand, clay and silt tend to have high transmissivity but relatively minimal storage capacity (Bhattacharya et al., 2012). Because of the lack of primary porosity, wells have had to be dug to depths of about $75 \mathrm{~m}$ in order to get a sizeable yield. The average well depth in the area is $35.4 \mathrm{~m}$. Borehole yields range between $0.4 \mathrm{~m}^{3} / \mathrm{h}$ to $18 \mathrm{~m}^{3} / \mathrm{h}$ with an average of 2.4 $\mathrm{m}^{3} / \mathrm{h}$ (Bhattacharya et al., 2012). In cases where the rocks are not fractured and weathered, the depth of the wells have no significant effect on the borehole yield. Weathering is greater in the Birimian formation with fissure depths ranging between (90-120) $\mathrm{m}$. In the Tarkwaian formation, however, fissure depths rarely exceed $20 \mathrm{~m}$ (Kortatsi, 2002). The Bonsa, Huni and Ankobra Rivers and their tributaries drain the area and in cases where hydraulic contact between streams and groundwater exist, borehole yields are greatly influenced (Bhattacharya et al., 2012). The development of groundwater is, however hampered by mine contaminants and mining related activities, leakage from underground storage tanks, improper waste disposal and agrochemicals from agricultural fields (Akabzaa, 2000).

\subsection{Hydro-chemical Information}

According to Yankey et al. (2011), groundwater temperature in the Tarkwa area ranges between 25.8 to $28.3{ }^{\circ} \mathrm{C}$. About $87.5 \%$ of groundwater has $\mathrm{pH}$ values below the recommended range of 6.5-8.5. Mean $\mathrm{pH}$ is 5.67 whiles median $\mathrm{pH}$ is 5.70 . Electrical conductivity (EC) ranges between $49-421 \mu \mathrm{S} / \mathrm{cm}$ with a median value of $148.1 \mu \mathrm{S} / \mathrm{cm}$ and a mean of $205.1 \mu \mathrm{S} / \mathrm{cm}$ for groundwater, whiles most surface waters range between $10-1000 \mu \mathrm{S} / \mathrm{cm}$. There is a strong correlation between the concentration of $\mathrm{Mg}, \mathrm{Ca}, \mathrm{HCO}_{3}{ }^{-}$and EC for groundwater in the area (Yankey et al., 2011). These ions are derived from carbonate dissolution in groundwater and are low in concentration probably due to the short residence time of groundwater. Alkalinity values range between $4.0-199.0 \mathrm{mg} / \mathrm{L}$. Where sodium $\left(\mathrm{Na}^{+}\right)$is dominant, $\mathrm{HCO}_{3}^{-}$alkalinity is high. This relationship between $\mathrm{Na}$ and $\mathrm{HCO}_{3}^{-}$may result from cation exchange, calcite precipitation and enrichment through evapotranspiration (Hayashi et al., 2004). The proportion of cation and anion concentrations for the area is generally in the order; $\mathrm{Na}>\mathrm{Ca}>\mathrm{Mg}>\mathrm{K}$ and $\mathrm{HCO}_{3}>\mathrm{Cl}>\mathrm{SO}_{4}$ (Yankey et al., 2011).

\section{Resources and Methods Used}

\subsection{Field Survey}

38 water samples were analysed for hydro-chemical information. These samples were taken from hand dug-wells (12), boreholes (20) and streams (6) within the Tarkwa area. Parameters such as $\mathrm{pH}$, temperature, electrical conductivity (EC), redox potential (Eh) and dissolved oxygen (DO) changes rapidly after sample collection and as such had to be measured at the various sampling locations.

\subsection{Water Analysis}

Determination of trace metals in samples was conducted using an Inductively Coupled Plasma Mass Spectrometry (ICP-MS). Through this technique, the concentration of trace metals including cadmium, chromium, lead and arsenic were measured for comparison with WHO standards. Determination of anions and cations was also done using ion chromatography (IC). Carbonate alkalinity for all 38 samples were determined using Total Inorganic Carbon (TIC) analyser.

Microsoft Excel was used to process results for these measurement. It was also used for the generation of correlation diagrams and scatter plots. The Geochemist's Workbench version 11.05 was used to determine $\mathrm{NH}_{4}^{+}$, carbonate, hardness, water types, Piper and the Durov diagrams. ArcMap and Surfer were employed in the digitization and visualization of maps. PhreeqC was used to determine charge imbalance errors, the distribution of species and saturation indices.

ArcMap version 10.3 was used to georeference the image of the study area and the concentrations of elements exceeding the WHO guideline for each sample were imported, overlaid and viewed as contours. This way it is possible to get a clear visual interpretation of the trend and distribution of elements.

\subsection{Geochemical Modelling}

A review of the saturation index of groundwater helps to investigate the thermodynamic control of the groundwater with respect to reactions with major carbonate minerals to estimate the degree to which the groundwater has equilibrated or if undersaturated or super-saturated. The saturation index of groundwater with respect to carbonate mineral precipitation may be expressed as:

$$
\mathrm{SI}=\log \left(\frac{\mathrm{IAP}}{\mathrm{K}_{\mathrm{SF}}}\right)
$$

Where SI is the saturation index, IAP is the ion activity product and KSP is the solubility product constant (Merkel et al., 2005). Since a value of 1 indicates a ten-fold supersaturation and a value of -2 signifies a hundred-fold undersaturation, an interval of -2 to 2 is chosen in order to obtain values that are reasonable for most minerals (Asklund and Eldvall, 2005). SI value below -2 signifies a solution 
that is undersaturated with respect to that mineral, whiles SI value exceeding +2 signifies a solution that is supersaturated in relation to the corresponding mineral.

The main focus of the geochemical modelling is the equilibrium and precipitation of oxides and hydroxides of aluminium, iron, manganese and lead. Reactive minerals such as gypsum, calcite and dolomite are presented irrespective of the magnitude of saturation (Asklund and Eldvall, 2005). Though the range of equilibrium is set at $-2<\mathrm{SI}<2$, it is important to note that not all mineral phases exceeding +2 will be precipitated. An example of such mineral is dolomite. A rapid precipitation of calcite can also be expected irrespective of how minimal the fold of supersaturation.

\section{Results and Discussion}

\subsection{On-Site Measured Parameters}

Table 1 shows the arithmetical summary of parameters that were measured immediately at sampling points. The lowest groundwater temperature was recorded at Goldfields Tarkwa mine area (GF-SBH2) as $21.5{ }^{\circ} \mathrm{C}$ and the highest measured at Bonsaso (BH-BS4) as $31.9{ }^{\circ} \mathrm{C}$. The average groundwater temperature was $28.27{ }^{\circ} \mathrm{C}$. The $\mathrm{pH}$ varies between 3.84 and 7.85 with an average of 6.18 . The lowest conductivity in the area was recorded at Tamso (BH-TM1) with a value of $210 \mu \mathrm{s} / \mathrm{cm}$ and the highest at Efuanta (WH-EF3) with a value of $902 \mu \mathrm{s} / \mathrm{cm}$. Average conductivity for the entire area was, therefore, calculated to be $473.28 \mu \mathrm{s} / \mathrm{cm}$. The Brahabobome stream (BB-Stream1) recorded the lowest level of redox potential with $57 \mathrm{mV}$, whiles the highest was recorded at Tamso (BH-TM1) with a value of $363 \mathrm{mV}$. Redox potential for the entire area, therefore, averaged $224.28 \mathrm{mV}$. The Brahabobome stream (BB-Stream1) and borehole GF-SB4 at Goldfields, recorded the lowest and highest oxygen values of $1.84 \mathrm{mg} / \mathrm{L}$ and $8.40 \mathrm{mg} / \mathrm{L}$ respectively with the average oxygen concentration calculated to be $5.10 \mathrm{mg} / \mathrm{L}$. Salinity for the area was generally low and negligible, ranging from 0 to $0.2 \mathrm{ppt}$. The highest amount of suspended solids was measured at the Bonsa River and the highest dissolved solids was measured at Efuanta (WH-EF3).

Fig. 4 shows the concentrations of $\mathrm{pH}$ and $\mathrm{Eh}$ in samples as measured directly on the field. Kriging was used to interpolate concentrations onto a digitized map of the study area in ArcGIS. Sampling locations are indicated with plus signs. The study area is predominantly of oxidizing acidic environment since almost $90 \%$ of the samples measured had low $\mathrm{pH}$ and positive Eh values.

\subsection{Cations and Anions}

Determination of electroneutrality was carried out and all the samples passes the test in which $\pm 10 \%$ was acceptable in the local content.

Piper and Durov's diagrams were constructed to illustrate the concentrations of cations and anions graphically. The Geochemist's Workbench version 11 was used to plot the diagrams. Figs. 3 and 5 show the Piper and Durov plots of concentrations of major ions measured in samples.

From the Piper diagram, most of the samples belong to $\mathrm{Ca}^{2+}-\mathrm{Mg}^{2+}-\mathrm{HCO}_{3}^{-}$, with concentrations of $\mathrm{Ca}^{2+}-\mathrm{Mg}$ making up $55.8 \%$ (Fig. 3). About 60 $\%$ of the samples have very high levels of bicarbonate $\left(\mathrm{HCO}_{3}{ }^{-}\right)$dominating the list of anions determined. The sequence of anion dominance is as follows: $\mathrm{HCO}_{3}^{-}, \mathrm{NO}_{3}^{-}, \mathrm{Cl}^{-}, \mathrm{SO}_{4}{ }^{2-}, \mathrm{NO}_{2}^{-}$and $\mathrm{PO}_{4}{ }^{3-}$. $\mathrm{Na}^{+}$is the dominant cation, determined in about 56 $\%$ of the samples. This is followed by $\mathrm{Ca}^{+}, \mathrm{Mg}^{2+}$ and $\mathrm{K}^{+}$in order of dominance.

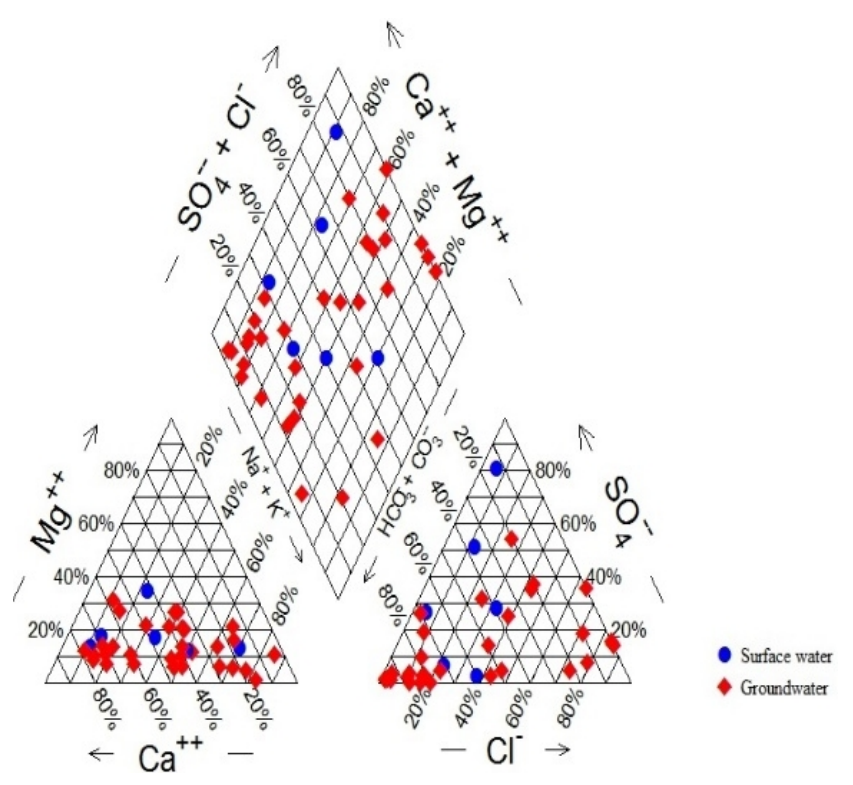

Fig. 3 Piper Diagram of Anions and Cations

From the Durov diagram (Fig. 5), 8 of the 38 samples representing $21 \%$ were along the dissolution line with no dominant cation or anion. This is characteristic of fresh recent recharge water that exhibits simple dissolution (Lloyd and Heathcote, 1985). 4 samples, representing $10.5 \%$ of the total samples indicate that these waters have $\mathrm{Na}$ and $\mathrm{Cl}$ as dominant cation/anion, hence an ion exchange activity between $\mathrm{Na}$ and $\mathrm{Cl}$ waters. 8 of the samples $(21 \%)$ have $\mathrm{HCO}_{3}$ and $\mathrm{Ca}$ as dominant anion/cation and hence a reverse ion exchange activity of $\mathrm{HCO}_{3}$ and $\mathrm{Ca}$ waters. 
Table 1 Summary of On-Site Parameters

\begin{tabular}{|c|c|c|c|c|c|c|c|c|c|}
\hline ID & $\begin{array}{c}\text { Samples } \\
\text { Description }\end{array}$ & $\begin{array}{c}\text { Temp } \\
\left({ }^{\circ} \mathrm{C}\right)\end{array}$ & pH & $\begin{array}{c}\text { Conductivity } \\
(\mu \mathrm{S} / \mathrm{cm})\end{array}$ & $\begin{array}{c}\text { Redox } \\
(\mathrm{mV})\end{array}$ & $\begin{array}{l}\text { Oxygen } \\
\text { mg/L }\end{array}$ & $\begin{array}{c}\text { Tot. Sus. } \\
\text { Solids } \\
(\mathrm{mg} / \mathrm{L}) \\
\end{array}$ & $\begin{array}{c}\text { Tot. Diss. } \\
\text { Solids } \\
\text { (mg/L) }\end{array}$ & Salinity \\
\hline 1 & CMH-BH & 28.0 & 5.75 & 142.5 & 235 & 3.46 & 4.18 & 97 & 0.0 \\
\hline 2 & Stream UMaT (m) & 29.0 & 7.67 & 677.0 & 244 & 7.13 & 38 & 441 & 0.1 \\
\hline 3 & Stream UMaT & 28.8 & 7.85 & 610.0 & 220 & 7.59 & 42 & 395 & 0.1 \\
\hline 4 & BB-BHI & 30.7 & 7.15 & 507.0 & 248 & 2.79 & 6.05 & 357 & 0.0 \\
\hline 5 & BB-HH & 29.9 & 5.75 & 95.7 & 219 & 5.58 & 9.04 & 67 & 0.0 \\
\hline 6 & WH-KP1 & 30.3 & 4.74 & 120.1 & 291 & 3.51 & 28.6 & 60 & 0.0 \\
\hline 7 & WH-KP2 & 29.6 & 6.04 & 109.9 & 341 & 7.30 & 16.22 & 65 & 0.0 \\
\hline 8 & WH-EF1 & 30.7 & 5.86 & 254 & 256 & 4.50 & 18.4 & 149 & 0.0 \\
\hline 9 & WH-EF2 & 30.2 & 5.91 & 698 & 266 & 5.52 & 10.01 & 403 & 0.1 \\
\hline 10 & WH-EF3 & 29.3 & 6.63 & 902 & 86 & 4.30 & 14.03 & 536 & 0.2 \\
\hline 11 & BH-TM1 & 27.6 & 4.19 & 210 & 363 & 4.56 & 6.3 & 129 & 0.0 \\
\hline 12 & WH-TM2 & 30.9 & 5.10 & 661 & 322 & 5.12 & 19.8 & 382 & 0.0 \\
\hline 13 & WH-TM3 & 30.5 & 5.32 & 488 & 277 & 3.50 & 16.4 & 283 & 0.0 \\
\hline 14 & BH-NS1 & 31.7 & 6.88 & 615 & 247 & 5.50 & $<1$ & 351 & 0.0 \\
\hline 15 & WH-NS2 & 28.5 & 6.07 & 537 & 252 & 3.90 & 18.72 & 525 & 0.0 \\
\hline 16 & BH-NS3 & 31.6 & 6.75 & 449 & 214 & 4.15 & 3.2 & 255 & 0.0 \\
\hline 17 & WH-KP3 & 31.8 & 6.38 & 362 & 252 & 5.01 & 12.5 & 205 & 0.0 \\
\hline 18 & BB-Streamn 1 & 27.4 & 6.46 & 199.4 & 57 & 1.84 & 52 & 123 & 0.0 \\
\hline 19 & BS_River 1 & 30.1 & 6.86 & 170.8 & 228 & 6.01 & 56 & 100 & 0.0 \\
\hline 20 & BH-BS 2 & 28.0 & 6.77 & 363 & 191 & 2.33 & 9.2 & 222 & 0.0 \\
\hline 21 & BH-BS 3 & 30.3 & 6.95 & 496 & 172 & 4.27 & 6.32 & 285 & 0.0 \\
\hline 22 & BH-BS 4 & 31.9 & 6.73 & 509 & 88 & 3.33 & 9.6 & 293 & 0.0 \\
\hline 23 & WH-BJ 1 & 28.6 & 5.81 & 155.5 & 244 & 6.52 & 8.45 & 94 & 0.0 \\
\hline 24 & BH-BJ 2 & 26.6 & 6.91 & 422 & 231 & 3.52 & 7.98 & 264 & 0.0 \\
\hline 25 & BH-BJ 3 & 26.8 & 4.36 & 177.1 & 333 & 2.56 & 8.59 & 111 & 0.0 \\
\hline 26 & BH-BJ 4 & 29.9 & 6.02 & 123.3 & 230 & 5.79 & 12 & 73 & 0.0 \\
\hline 27 & BJ-Stream 5 & 30.7 & 7.14 & 83.7 & 213 & 6.91 & 41 & 48 & 0.0 \\
\hline 28 & Huni River & 28.2 & 6.89 & 186.4 & 187 & 6.74 & 49 & 112 & 0.0 \\
\hline 29 & BH-HN 2 & 28.3 & 3.84 & 688 & 254 & 3.54 & 7.4 & 415 & 0.1 \\
\hline 30 & WH-HN 3 & 28.0 & 5.29 & 136.3 & 237 & 2.35 & 16.8 & 85 & 0.0 \\
\hline 31 & WH-AP 1 & 29.5 & 5.47 & 276 & 210 & 4.59 & 23.3 & 164 & 0.0 \\
\hline 32 & GF-SBH 2 & 21.5 & 5.93 & 124.1 & 232 & 8 & 6.12 & 85 & 0.0 \\
\hline 33 & GF-SBH 4 & 21.7 & 6.35 & 261 & 217 & 8.4 & 6.02 & 178 & 0.0 \\
\hline 34 & GF-NBH 2 & 22.7 & 6.12 & 139.4 & 199 & 6.9 & 16.2 & 94 & 0.0 \\
\hline 35 & GF-NBH 14 & 24.4 & 6.91 & 481 & 203 & 6.6 & 6.53 & 322 & 0.0 \\
\hline 36 & GF-NBH 19 & 23.7 & 6.68 & 250 & 94 & 6.6 & 8.68 & 169 & 0.0 \\
\hline 37 & GF-NBH 20 & 23.4 & 6.87 & 498 & 212 & 6.7 & 8.78 & 334 & 0.0 \\
\hline 38 & GF-NBH 21 & 23.6 & 6.47 & 447 & 248 & 6.8 & 3.17 & 300 & 0.0 \\
\hline
\end{tabular}



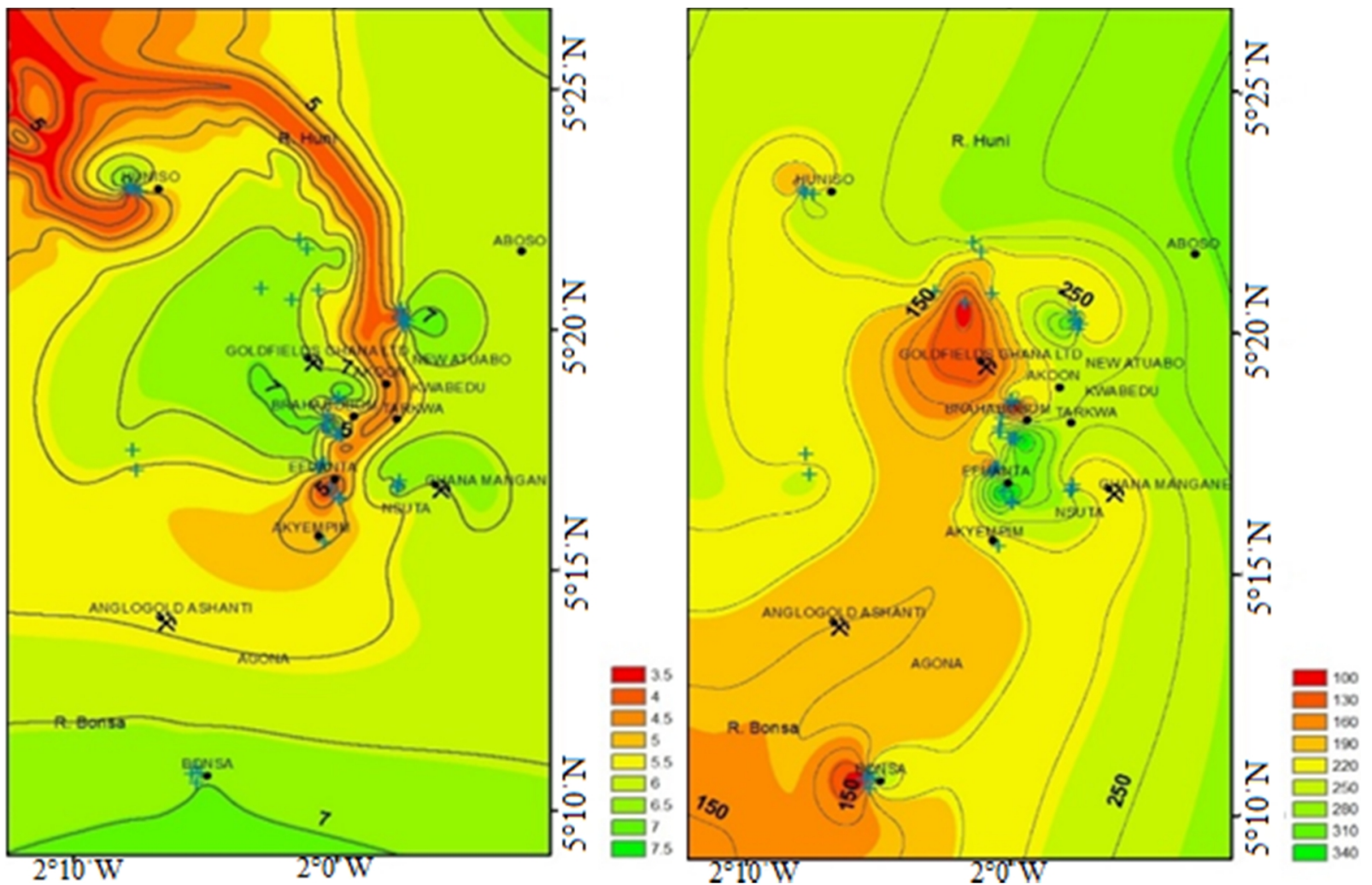

Fig. 4 Measured pH to the Left and Eh (mV) to the Right

3 samples representing $8 \%$ indicate waters with dominant $\mathrm{Na}$ and anion discriminant. The remaining 15 samples $(39.5 \%)$ indicate $\mathrm{HCO}_{3}$ and $\mathrm{Ca}$ dominate. The Geochemist's Workbench was used to analyse the IC and ICP-MS results for water types based on ion dominance. About $32 \%$ of the samples have a calcium bicarbonate $\left(\mathrm{Ca}-\mathrm{HCO}_{3}\right)$ water type. Another $13 \%$ of the samples were determined to be of a $\mathrm{Na}-\mathrm{HCO}_{3}$ water type.

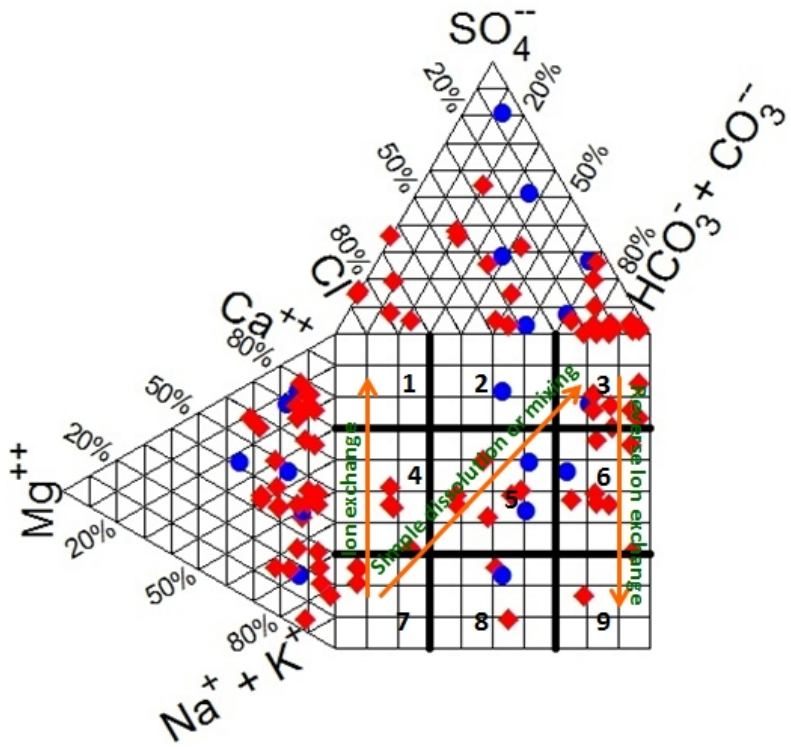

Fig. 5 Durov Diagram of Ions, pH and Total Dissolved Solids
This trend of carbon-containing species is usual since bicarbonate is mostly predominant with $\mathrm{pH}$ range of 6.36 to 10.25 . Other water types determined include $\mathrm{Na}-\mathrm{Cl}$, which represents $35 \%$ of the 38 samples and $\mathrm{Ca}-\mathrm{SO}_{4}{ }^{2-}$ and $\mathrm{Ca}-\mathrm{Cl}$ water types all having $10 \%$ each. The trend of alkaline earth dominance may be as a result of $\mathrm{Ca}$ replacing $\mathrm{Na}$ and extend $\mathrm{Mg}$ on ion exchange sites in the soil matrix as the age of the groundwater increases (Bhattacharya et al., 2012).

Analysing these diagrams for differences in ground and surface water, the Durov diagram does not show much variation in terms of the trend of mixing or solutions. However, the Piper diagram shows that surface water is in the region of no action anion pair. Unlike groundwater, $83 \%$ of surface water samples plot in the middle of the $\mathrm{SO}_{4}{ }^{-}+\mathrm{Cl}^{-}$and $\mathrm{HCO}_{3}{ }^{-}+\mathrm{CO}_{3}^{-}$plot and not skewed towards a particular pair indicating water from an intermediate chemical character.

\subsection{Trace Metals}

Concentrations of most metals like $\mathrm{Cs}, \mathrm{Sb}, \mathrm{Se}, \mathrm{Tl}$, $\mathrm{Te}$ and In were generally low. A total of 30 samples had metal concentrations that exceed WHO guidelines. Concentration of arsenic in groundwater is generally low ranging from 0.0002 to $2.3 \mathrm{mg} / \mathrm{L}$ with most of the samples falling within the acceptable limit, except for four samples which had elevated values. These four samples were taken from hand-dug wells situated close to Goldfields Tarkwa Mine which is resident to some of the mine 
workers. The high concentrations indicate the weathering and the leaching of sulphur-bearing mine tailings into the subsurface. Manganese is a needed element but is also known for its mutagenicity. It was determined to exceed the WHO guideline of $0.4 \mathrm{mg} / \mathrm{L}$ in 7 sampling locations with 4 locations recording elevated $\mathrm{Mn}$ concentrations ranging from 0.77 to $1.26 \mathrm{mg} / \mathrm{L}$. Iron was detected in excess concentrations in only 4 of the water samples with one of them being surface water (BB-Stream 1). For areas such as Efuanta (WH-EF2) and the Bonsa River (BS-River1), high concentrations of $\mathrm{Fe}$ and $\mathrm{SO}_{4}{ }^{2-}$ together with low $\mathrm{pH}$ values signify the influence of acid mine drainage on groundwater in the area. Lead exceeds the WHO guideline marginally in only one location, BH-HN2 in Huniso. Potassium exceeds WHO guideline value in 2 locations, WHKP2 and WH-EF2. Nitrite exceeds the WHO guideline in 25 different sample locations.

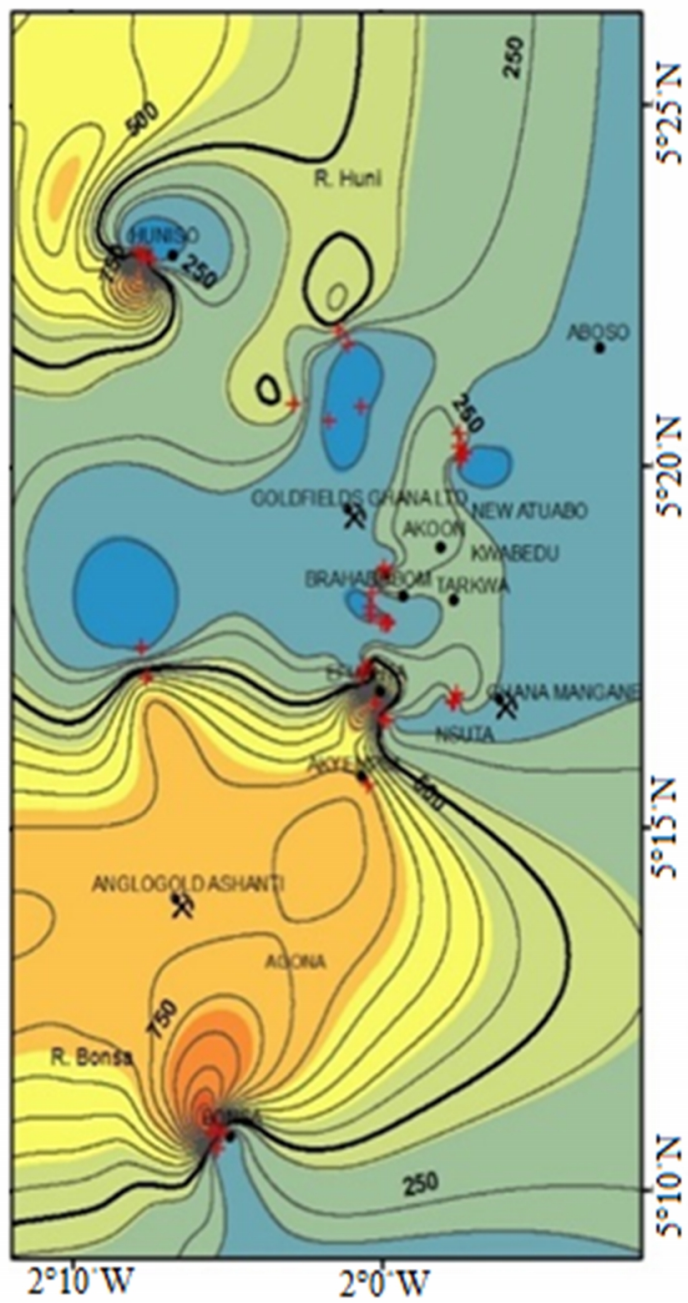

Excess nitrate was recorded in 8 samples. Concentration of nitrate in water is alarming since 4 sampling locations measured elevated concentrations ranging from 123 to $238 \mathrm{mg} / \mathrm{L}$.

Figs. 6 to 9 show concentration of metals in groundwater for the Tarkwa area. The thicker, darker line in each figure shows from which point concentration exceeds WHO guideline values. In terms of similarities or differences in the pattern of distribution of elements in the study area, no visible trend can be seen between the elements analysed (Figs. 6 to 9).

Each element has a different trend in areas where concentrations exceed the WHO guideline. To prove the relationship between the patterns of distribution of these elements, further analysis was done using correlation diagrams.

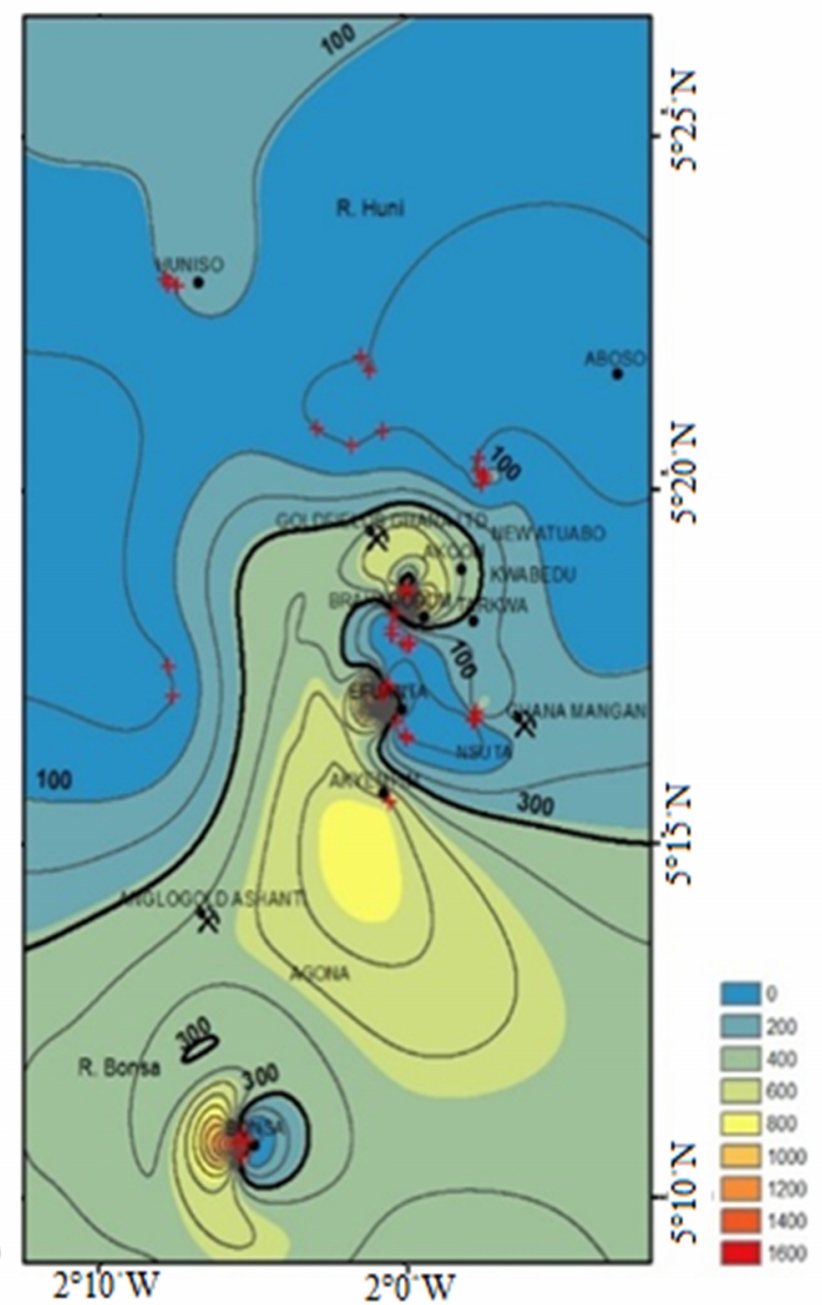

Fig. 6 Concentration of Manganese to the Left and Iron to the Right both in $\mu \mathrm{g} / \mathrm{L}$ 

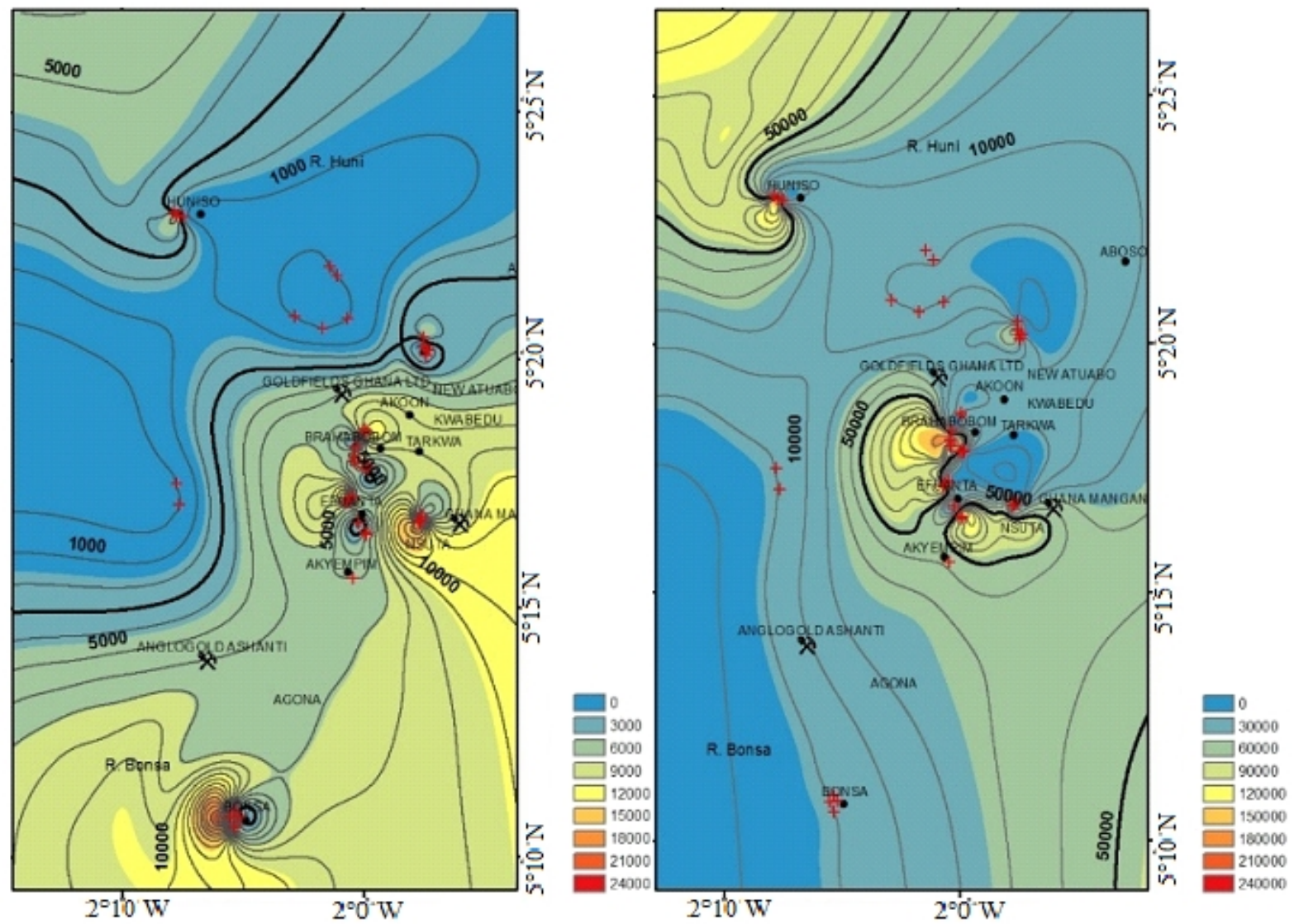

Fig. 7 Concentration of Nitrite to the Left and Nitrate to the Right both in $\mu \mathrm{g} / \mathrm{L}$
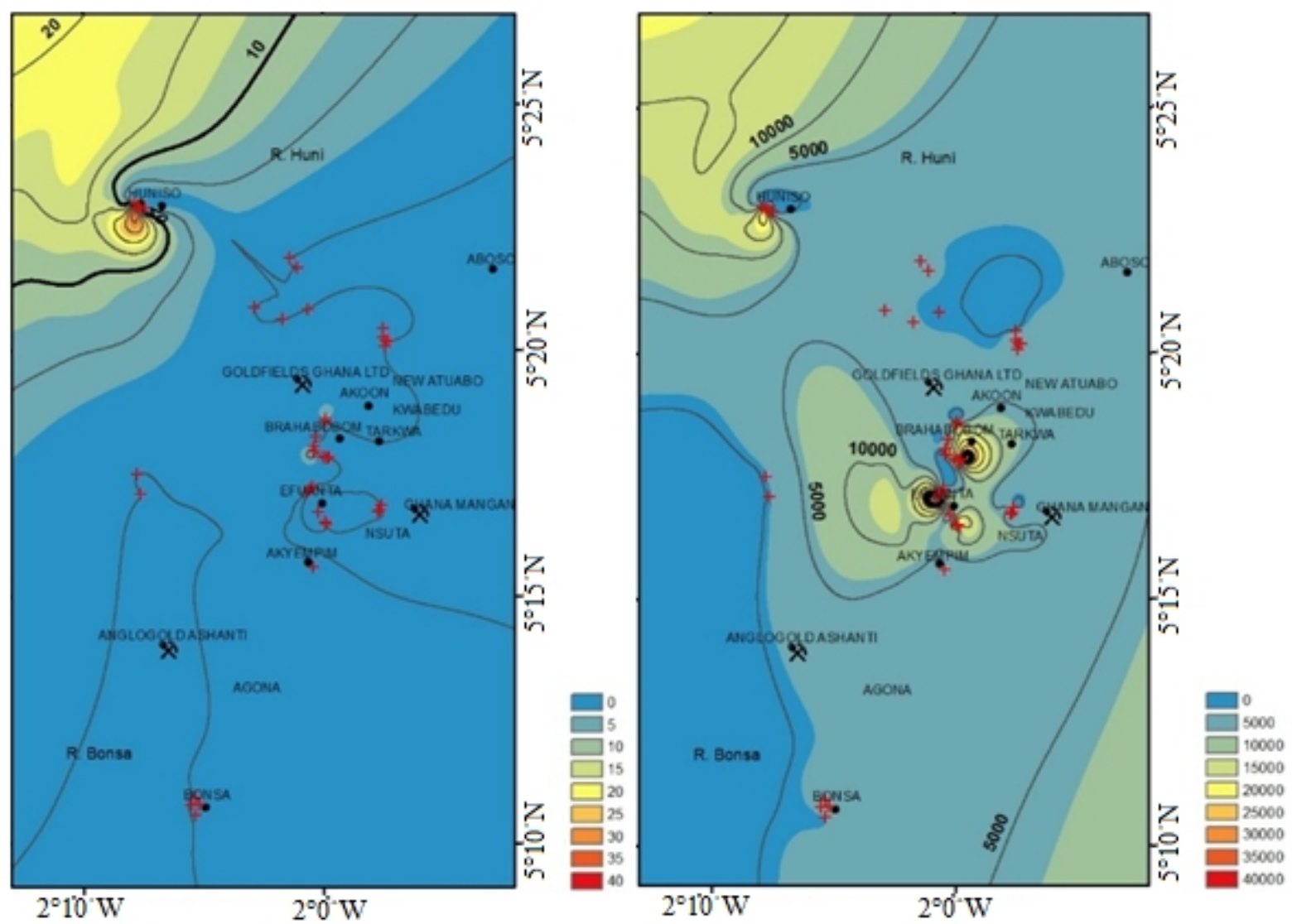

Fig. 8 Concentration of Lead to the Left and Potassium to the Right both in $\mu \mathrm{g} / \mathrm{L}$ 


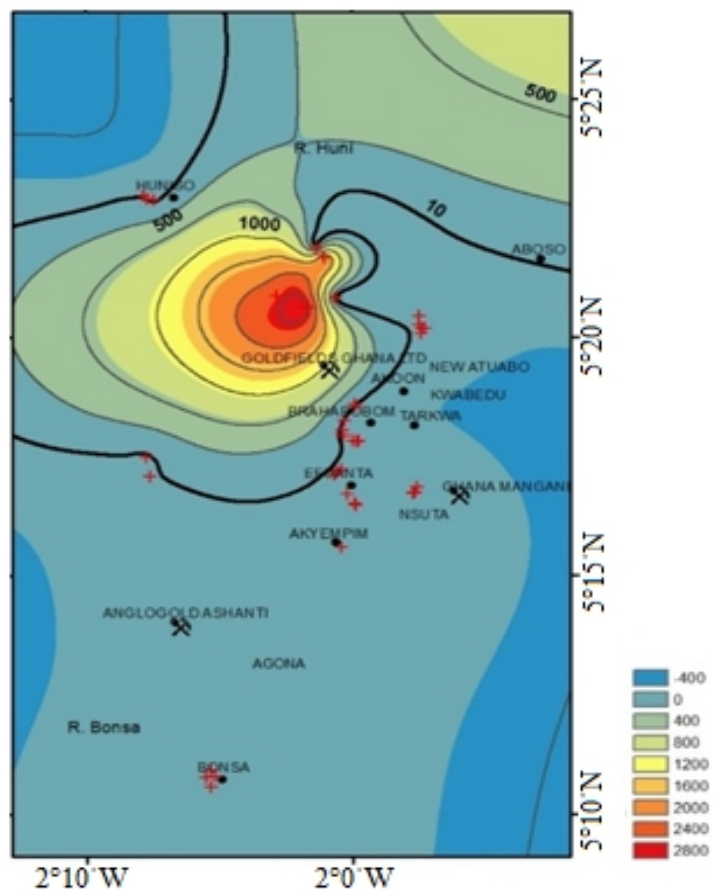

Fig. 9 Measured Concentration of Arsenic in $\mu \mathrm{g} / \mathrm{L}$

In Fig. 10, mineralisation of $\mathrm{Mn}$ and Fe in the soil occur at a similar ratio therefore the concentration and distribution of $\mathrm{Mn}$ and $\mathrm{Fe}$ in the soil is mostly positively correlated. The plot of $\mathrm{Mn}$ and Fe show a regression of $\mathrm{R}=0.243$. The poor correlation between the two could be explained by the precipitation of $\mathrm{Fe}$ under oxidising conditions thereby acting as a sink for total Fe. Fe oxides and hydroxides like goethite, hematite and magnetite are mostly supersaturated and can precipitate.

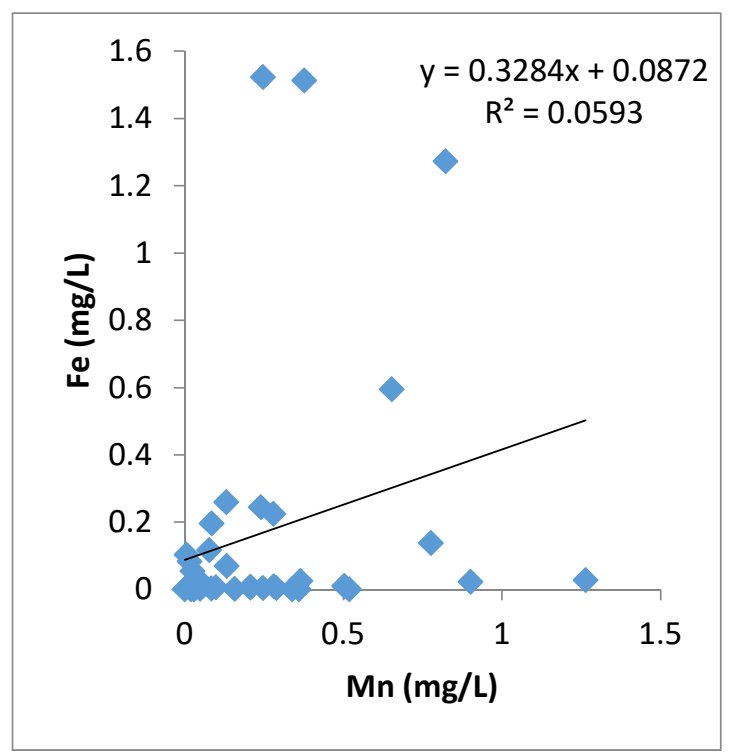

Fig. 10 Diagram showing Correlation for Fe and Mn
Manganese and Iron are members of the first row transition series of elements, consisting of Sc, Ti, $\mathrm{V}, \mathrm{Cr}, \mathrm{Mn}, \mathrm{Fe}, \mathrm{Co}, \mathrm{Ni}, \mathrm{Cu}$ and $\mathrm{Zn}$ and are mostly predominant in geological environments rich in sulphur. From Figs. 11 and 12, again $\mathrm{Mn}$ and $\mathrm{Fe}$ distributions do not show a similarity in correlation with $\mathrm{SO}_{4}{ }^{2-}$. $\mathrm{Mn}$ and $\mathrm{SO}_{4}{ }^{2-}$ have a regression $\mathrm{R}=0.063$ whiles $\mathrm{Fe}$ and $\mathrm{SO}_{4}{ }^{2-}$ have $\mathrm{R}=0.099$. The relationship between $\mathrm{Mn}, \mathrm{Fe}$ and $\mathrm{SO}_{4}{ }^{2-}$ in this case is, however, influenced by the sorptive capacity of the soil type in the area and redox processes.

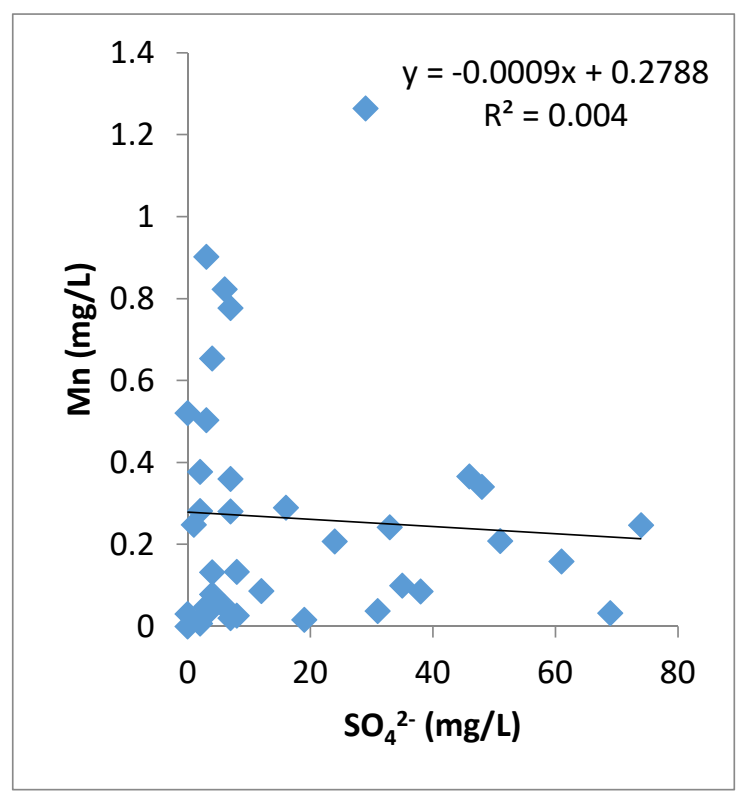

Fig. 11 Diagram showing Correlation for Mn and $\mathrm{SO}_{4}{ }^{2-}$

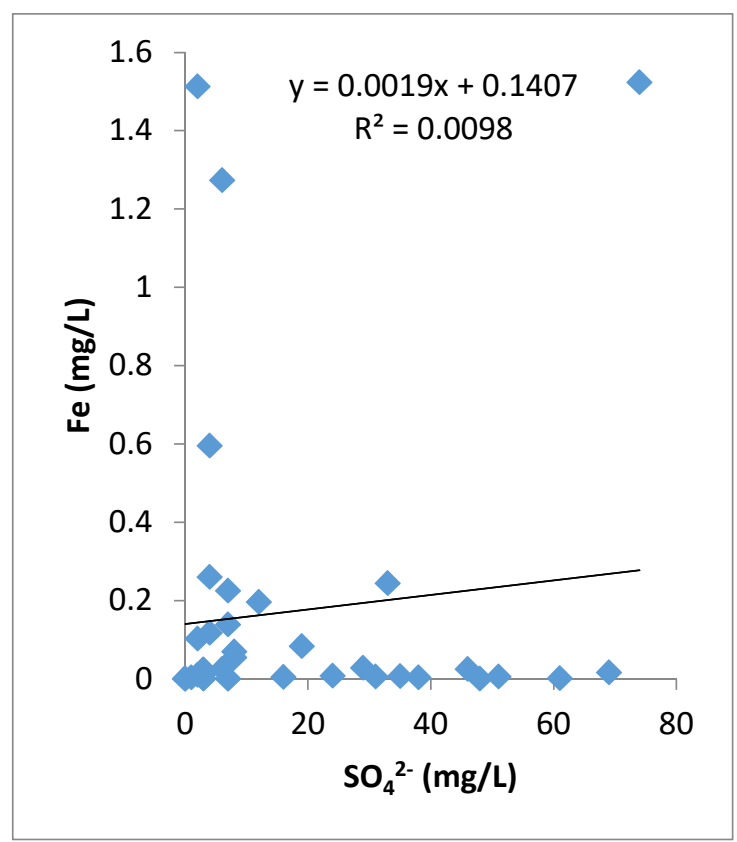

Fig. 12 Diagram showing Correlation for Fe and $\mathrm{SO}_{4}{ }^{2-}$ 
$\mathrm{SO}_{4}{ }^{2-}$ can be transformed through redox reactions to $\mathrm{H}_{2} \mathrm{~S}$, indicating that AMD may still exist in the study area despite the lack of correlation. Also, on observing the pattern of $\mathrm{SO}_{4}{ }^{2-}$ and $\mathrm{Eh}$, there is no visible trend since $\mathrm{SO}_{4}{ }^{2-}$ is evenly distributed at high and low Eh but maximized between Eh (200-300) $\mathrm{mV}$.

$\mathrm{Mn}$ and $\mathrm{Fe}$ can also be transformed through redox reactions. $\mathrm{Mn}^{4+}$ is reduced to $\mathrm{Mn}^{2+}$ and $\mathrm{Fe}^{2+}$ is oxidised to $\mathrm{Fe}^{3+}$. $\mathrm{Fe}^{3+}$ can further precipitate, thereby acting as a sink for total Fe. The presence of minerals like rhodochrosite and siderite under reducing conditions, may precipitate thereby acting as sinks for $\mathrm{Fe}$ and $\mathrm{Mn}$ (Asklund and Eldvall, 2005).

However, when $\mathrm{Ca}$ is plotted against $\mathrm{pH}$, there is a correlation. In most geological environments rich in sulphide minerals, calcium reacts with sulphate increasing the $\mathrm{pH}$. Hence, in such environments, low $\mathrm{Ca}$ concentration would mean low $\mathrm{pH}$ since there is insufficient $\mathrm{Ca}$ to react with $\mathrm{SO}_{4}$. As can be seen in Fig. 13, Ca shows a moderate correlation $(\mathrm{R}=0.54)$ with $\mathrm{pH}$.

The concentration of calcium in each solution is assumed to be obtained from the $\mathrm{Ca}$ content of $\mathrm{CaCO}_{3}$. Since carbon (specifically carbon trioxide) is not determined in the study as a separate element but as $\mathrm{HCO}_{3}$, establishing a correlation between $\mathrm{Ca}$ and $\mathrm{HCO}_{3}$ as shown in Fig. 14 indicates that there is a strong (positive) correlation between $\mathrm{Ca}$ and $\mathrm{HCO}_{3}$, with $\mathrm{R}=0.73$.

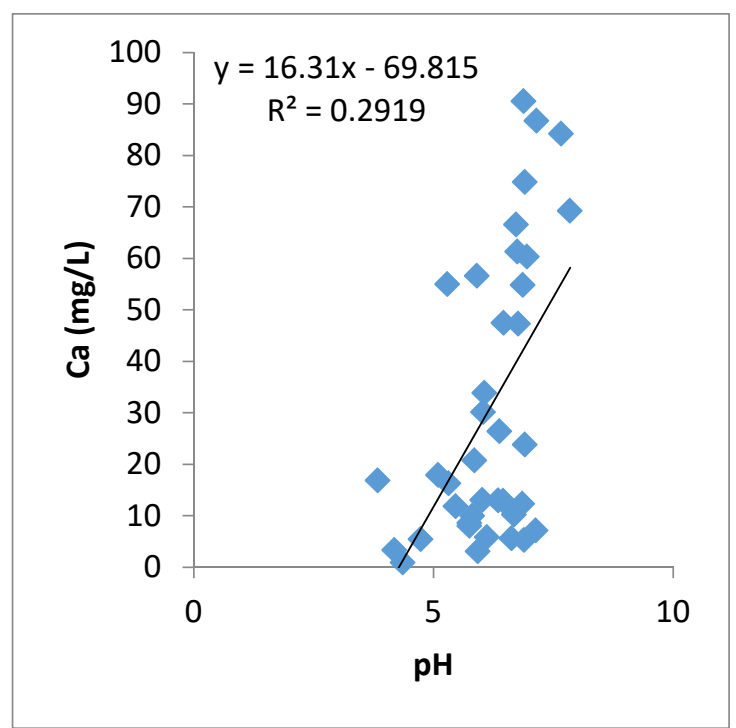

Fig. 13 Diagram showing Correlation for Ca and $\mathbf{p H}$

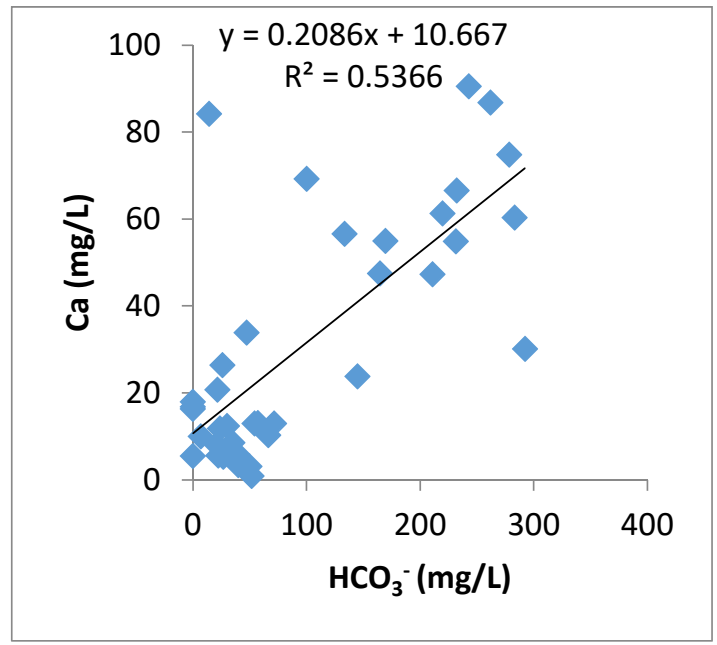

Fig. 14 Diagram showing Correlation for $\mathrm{Ca}$
and $\mathrm{HCO}_{3}^{-}$

Comparison of concentrations of trace metals with WHO guideline values based on the source or type of water indicates that for manganese, $83 \%$ of the samples that exceeded the WHO guideline were from boreholes, with the remaining $17 \%$ coming from hand-dug wells (HDW). For nitrate, $62.5 \%$ of the samples from hand-dug wells had values exceeding the guideline, recording the highest percentage, $25 \%$ for stream and $12.5 \%$ for borehole. For iron, borehole constituted $25 \%$, HDW $50 \%$ and stream also $25 \%$, for samples that exceeded the WHO guideline. When these values were plotted, not much difference could be seen since all three water supply facilities had values exceeding the guideline. For arsenic, all four samples that exceeded the WHO guideline came from boreholes. Only one sample exceeded the guideline for lead and this came from a borehole. For nitrite, borehole constituted $60 \%$, hand-dug well $20 \%$ and stream $20 \%$, for samples that exceeded the guideline. For potassium, the only sample that exceeded the WHO guideline came from a hand-dug wells. Values for $\mathrm{pH}$ were also plotted to see differences in the three water supply facilities. Stream had 2, the least number of samples falling outside the WHO acceptable range, HDW represented $55 \%$ of the total number of samples that fell outside the WHO acceptable range, while borehole represented $40 \%$ respectively. Not much difference was seen when values for Eh were plotted. Among the toxic elements, mercury $(\mathrm{Hg})$ was not analysed since it is known to sorb onto polyethylene (PET) surfaces. Considering the fact that samples taken from the field were kept in PET bottles and stored in a refrigerator for 5 weeks before being transported to Germany for analysis and also that the ICP-MS instrument has a plastic tube that draws samples into the system, a large concentration of $\mathrm{Hg}$ would be sorbed onto these PET surfaces, thereby altering the results of the analysis. 
Table 2 Results of Modelling with PhreeqC showing the Distribution of Species

\begin{tabular}{|c|c|c|c|c|c|c|}
\hline Mineral & Species & $\begin{array}{c}\text { Samp. } 3 \\
(\%)\end{array}$ & $\begin{array}{c}\text { Samp. } 11 \\
(\%)\end{array}$ & $\begin{array}{c}\text { Samp. } 15 \\
(\%)\end{array}$ & $\begin{array}{c}\text { Samp. } 22 \\
(\%)\end{array}$ & $\begin{array}{c}\text { Samp. } 29 \\
(\%)\end{array}$ \\
\hline \multirow[t]{8}{*}{$\mathrm{Fe}(2)$} & $\mathrm{Fe}^{+2}$ & 1.34 & 93.99 & 89.53 & 77.19 & 97.33 \\
\hline & $\mathrm{FeHCO}_{3}{ }^{+}$ & 0.14 & 5.55 & 4.88 & 20.35 & 0.00 \\
\hline & $\mathrm{FeCO}_{3}$ & 0.11 & 0.00 & 0.06 & 1.28 & 0.00 \\
\hline & $\mathrm{FeSO}_{4}$ & 0.03 & 0.33 & 4.73 & 0.40 & 2.31 \\
\hline & $\mathrm{FeOH}^{+}$ & 0.03 & 0.00 & 0.03 & 0.17 & 0.00 \\
\hline & $\mathrm{FeHPO}_{4}$ & 0.00 & 0.00 & 0.01 & 0.41 & 0.00 \\
\hline & $\mathrm{FeCl}^{+}$ & 0.00 & 0.07 & 0.14 & 0.01 & 0.31 \\
\hline & $\mathrm{FeH}_{2} \mathrm{PO}_{4}{ }^{+}$ & 0.00 & 0.06 & 0.02 & 0.16 & 0.04 \\
\hline \multirow[t]{3}{*}{$\mathrm{Fe}(3)$} & $\mathrm{Fe}(\mathrm{OH})_{3}$ & 82.98 & 0.00 & 0.09 & 0.02 & 0.00 \\
\hline & $\mathrm{Fe}(\mathrm{OH})_{2}^{+}$ & 8.52 & 0.01 & 0.54 & 0.03 & 0.00 \\
\hline & $\mathrm{Fe}(\mathrm{OH})_{4}^{-}$ & 6.87 & 0.00 & 0.00 & 0.00 & 0.00 \\
\hline \multirow[t]{7}{*}{ Al } & $\mathrm{Al}(\mathrm{OH})_{4}^{-}$ & 99.30 & 0.00 & 28.10 & 0.00 & 0.00 \\
\hline & $\mathrm{Al}(\mathrm{OH})_{3}$ & 0.64 & 0.00 & 11.05 & 0.00 & 0.00 \\
\hline & $\mathrm{Al}(\mathrm{OH})_{2}{ }^{+}$ & 0.05 & 1.55 & 54.20 & 0.00 & 0.22 \\
\hline & $\mathrm{AlOH}^{+2}$ & 0.00 & 11.82 & 5.65 & 0.00 & 4.05 \\
\hline & $\mathrm{Al}^{+3}$ & 0.00 & 82.36 & 0.59 & 0.00 & 73.96 \\
\hline & $\mathrm{AlSO}_{4}^{+}$ & 0.00 & 4.25 & 0.39 & 0.00 & 21.64 \\
\hline & $\mathrm{Al}\left(\mathrm{SO}_{4}\right)_{2}^{-}$ & 0.00 & 0.00 & 0.00 & 0.00 & 0.12 \\
\hline \multirow[t]{12}{*}{$\mathbf{P b}$} & $\mathrm{PbCO}_{3}$ & 93.56 & 0.50 & 23.48 & 78.74 & 0.00 \\
\hline & $\mathrm{Pb}\left(\mathrm{CO}_{3}\right)_{2}{ }^{-2}$ & 1.76 & 0.00 & 0.00 & 0.27 & 0.00 \\
\hline & $\mathrm{PbOH}^{+}$ & 1.61 & 0.02 & 0.81 & 0.53 & 0.01 \\
\hline & $\mathrm{Pb}^{+2}$ & 1.56 & 66.25 & 45.90 & 6.56 & 83.84 \\
\hline & $\mathrm{PbHCO}_{3}^{+}$ & 1.32 & 31.06 & 19.87 & 13.74 & 0.00 \\
\hline & $\mathrm{PbSO}_{4}$ & 0.11 & 0.71 & 7.20 & 0.10 & 5.94 \\
\hline & $\mathrm{PbNO}_{3}^{+}$ & 0.06 & 0.00 & 0.53 & 0.00 & 1.77 \\
\hline & $\mathrm{Pb}(\mathrm{OH})_{2}$ & 0.04 & 0.00 & 0.00 & 0.00 & 0.00 \\
\hline & $\mathrm{PbCl}^{+}$ & 0.01 & 1.44 & 2.19 & 0.04 & 8.39 \\
\hline & $\mathrm{Pb}\left(\mathrm{SO}_{4}\right)_{2}^{-2}$ & 0.00 & 0.00 & 0.02 & 0.00 & 0.01 \\
\hline & $\mathrm{PbBr}^{+}$ & 0.00 & 0.00 & 0.00 & 0.00 & 0.01 \\
\hline & $\mathrm{PbCl}_{2}$ & 0.00 & 0.00 & 0.00 & 0.00 & 0.03 \\
\hline \multirow[t]{6}{*}{$\operatorname{Mn}(2)$} & $\mathrm{Mn}^{+2}$ & 71.64 & 94.52 & 90.22 & 77.17 & 96.79 \\
\hline & $\mathrm{MnCO}_{3}$ & 19.69 & 0.00 & 0.21 & 4.23 & 0.00 \\
\hline & $\mathrm{MnHCO}_{3}{ }^{+}$ & 6.82 & 4.97 & 4.385 & 18.14 & 0.00 \\
\hline & $\mathrm{MnSO}_{4}$ & 1.69 & 0.34 & 4.78 & 0.40 & 2.31 \\
\hline & $\mathrm{MnOH}^{+}$ & 0.13 & 0.00 & 0.00 & 0.01 & 0.00 \\
\hline & $\mathrm{MnCl}^{+}$ & 0.03 & 0.20 & 0.40 & 0.04 & 0.91 \\
\hline
\end{tabular}




\subsection{Geochemical Modelling}

Based on the concentration of metals and $\mathrm{pH}$ values, samples $3,11,15,22$ and 29 were selected for geochemical speciation modelling because they are representative samples from the different geological formations in Tarkwa. These sampling points were also selected taking into consideration the different types or sources of the samples, with at least one sample representing either borehole, hand-dug well or stream. The result of the geochemical analysis with PhreeqC indicates that lead carbonate, lead hydroxide and lead sulphate among others, are all undersaturated with respect to those solid phases by several orders of magnitude.

From the results of the PhreeqC modelling (Table 2 ), it is noteworthy that Mn predominantly occurs as free ion with the species $\mathrm{Mn}^{2+}$ taking up approximately $72 \%, 94 \%, 90 \%, 77 \%$ and $97 \%$ of the total molality of Mn in samples 3, 11, 15, 22 and 29 respectively. Fe also occurs predominantly as a free ion except in sample 3 where it can be seen to form the complex $\mathrm{Fe}(\mathrm{OH})_{3}$, representing 83 $\%$ of the total molality. In samples 3 and $22, \mathrm{~Pb}$ is seen to form complexes with carbonate as $\mathrm{PbCO}_{3}$, making up $93 \%$ and $79 \%$ of their respective total molalities. $\mathrm{Pb}$, however, occurs predominantly as a free ion in samples 11, 15 and 29. Al also occurs as a free ion in samples 11 and 29 and as hydroxide complexes in samples 3 and 15.

Comparison of results with previous studies as shown in Fig. 15 and 16 indicate that concentration levels of metals had declined. These could be attributed to the fact that discharge from major mining operations has seen major improvements in treatment procedures.

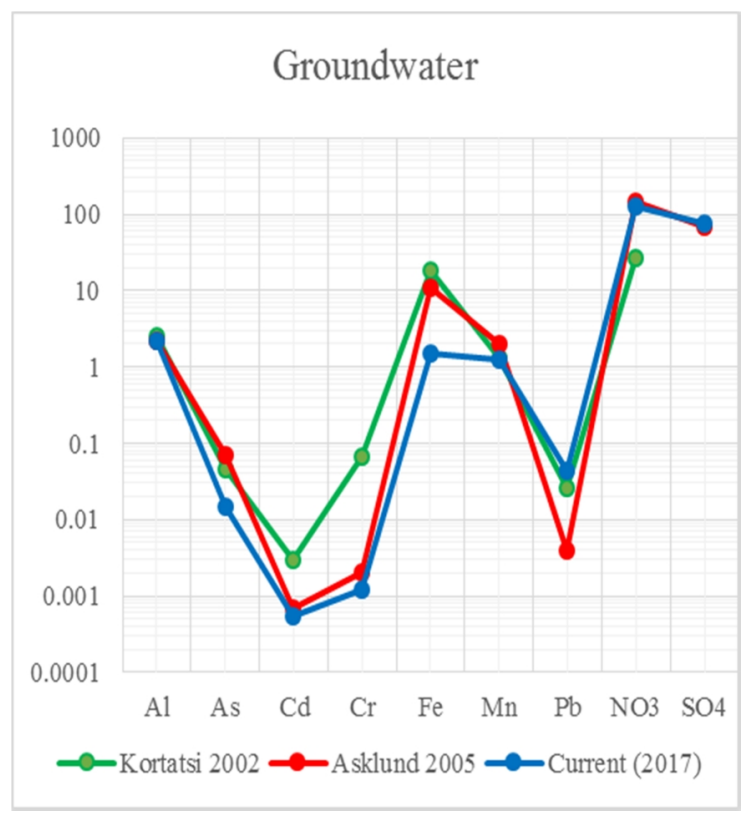

Fig. 15 Comparison of Concentration of Metals to Previous Research Works in Groundwater

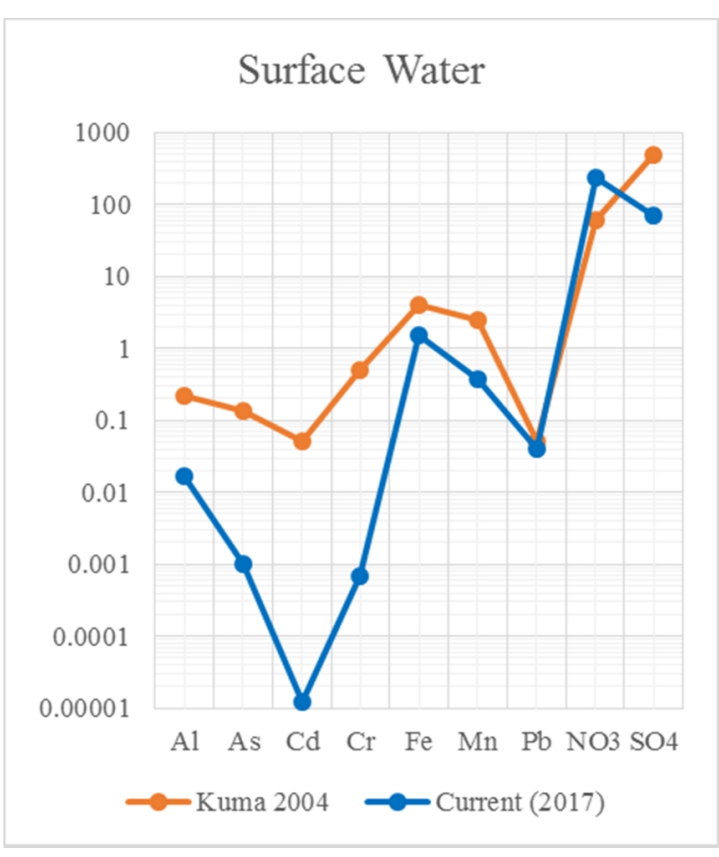

Fig. 16 Comparison of Concentration of Metals to Previous Research Works in Surface Water

This can be explained by the fact that Goldfields Ghana Ltd commissioned two discharge-water treatment facilities which improve the quality of discharge water and optimize its reuse. The development of agricultural activities and other significant landuse forms could positively influence the spread of metals thereby minimising the effects of AMD in the study area.

\section{Conclusions and Recommendations}

\subsection{Conclusions}

Results of on-site measurements and analysis of physico-chemical parameters reveal that $55 \%$ of the samples have $\mathrm{pH}$ values that are outside WHO's acceptable range.

The elevated As-levels indicate the weathering of arsenopyrite and the leaching of sulphur bearing mine tailings into the subsurface. Another instance is Efuanta (WH-EF2) and the Bonsa River (BS-River1), where there are high concentrations of $\mathrm{Fe}$ and $\mathrm{SO}_{4}{ }^{2-}$ coupled with low $\mathrm{pH}$. This suggest the influence of acid mine drainage on groundwater in these areas. Even in places like Akyempim (WH-AP1), Brahabobome (BB-Stream1) and Bonsaso (BH-BS4) where there is high Fe but low $\mathrm{SO}_{4}{ }^{2-}, \mathrm{AMD}$ cannot be ruled out since $\mathrm{SO}_{4}{ }^{2-}$ can be transformed through redox reactions to $\mathrm{H}_{2} \mathrm{~S}$. Also in places where there exists high $\mathrm{SO}_{4}{ }^{2-}$ but low $\mathrm{Fe}$, AMD could still be prevalent since the low levels of $\mathrm{Fe}$ could be explained by the presence of 
minerals like rhodochrosite and siderite which often act as sinks for $\mathrm{Fe}$ in oxidizing conditions. On analysing the trend of metal concentration based on the 3 water supply facilities (borehole, hand-dug well and stream), there is no significant difference since the impact of AMD can be seen almost equally in all three water supply facilities.

The general trend of water quality for the Tarkwa area is not as bad as previous studies have portrayed. This research work together with some recent studies such as Kuma and Ewusi, (2010), show that the trend of metal distribution has seen improvements in concentration levels.

\subsection{Recommendations}

Arduous efforts should be made by governmental institutions, mining operators and other policy makers like district or municipal assemblies, EPA and chiefs, to ensure frequent monitoring and implementation of safe mining practices so as not to disembark on the seemingly slightly improved quality of groundwater in the area. Monitoring plan should include the frequent collection and analysis of surface and groundwater to identify changes that may occur in the environment.

\section{References}

Agyapong, P. A. and Otoo, Rhoda Y. A. (2014), "District Analytical Report, Tarkwa Nsuaem Municipality", Archaeometry, 45 pp.

Akabzaa, T. M. (2000), Boom and Dislocation "The Environmental and Social Impacts of Mining in the Wassa West District of Ghana", Third World Network-Africa, pp. 17-22.

Amasa, S. K. (1975), "Arsenic Pollution at Obuasi Goldmine, Town and Surrounding Countryside" Environmental Health Perspectives Vol. 12, p. 131

Asante, K. A., Agusa, T., Subramanian, A., AnsaAsare, O. D., Biney, C. A. and Tanabe, S. (2007), "Contamination status of arsenic and other trace elements in drinking water and residents from Tarkwa, a historic mining township in Ghana", Chemosphere 66 (8), pp. 1513-1522.

Asklund, R. and Eldvall, B. (2005), "Contamination of water resources in Tarkwa mining area of Ghana", Lund, Sweden: KFS AB, 27 (3), pp. 61-75.

Babut, M., Sekyi, R., Rambaud, A., Potin-Gautier, M., Tellier, S., Bannerman, W. and Beinhoff, C. (2003), "Improving the environmental management of small-scale gold mining in Ghana: A case study of Dumasi", Journal of Cleaner Production, 11 (2), pp. 215-221.

Bhattacharya, P., Sracek, O., Eldvall, B., Asklund, R., Barmen, G. and Jacks, G. (2012), "Hydrogeochemical study on the contamination of water resources in a part of Tarkwa mining area, Western Ghana", Journal of African Earth Sciences, pp. 72-84.

Buxeda, I. G. J., Cau Ontiveros, M. A. and Kilikoglou, V. (2003), "Chemical Variability in Clays and Pottery from a Traditional Cooking Pot Production Village: Testing Assumptions in Pereruela", Archaeometry, 45 (1), pp. 1-17.

Dapaah-Siakwan, S. and Gyau-Boakye, P. (2000), "Hydrogeologic framework and borehole yields in Ghana", Hydrogeology Journal, 8 (4), pp. $405-416$.

Dzigbodi-Adjimah, K. (1993), "Geology and geochemical patterns of the Birimian gold deposits, Ghana, West Africa", Journal of Geochemical Exploration, 47 (1-3), pp. 305320.

Hayashi, M., Quinton, W. L., Pietroniro, A. and Gibson, J. J. (2004), "Hydrologic functions of wetlands in a discontinuous permafrost basin indicated by isotopic and chemical signatures", Journal of Hydrology, 296 (1-4), pp. 81-97.

Junner, N. R., Hirst, T. and Service, H. (1942), "The Tarkwa Goldfield. Gold Coast Geological Survey", Environmental Geology, pp. 48-55.

Kortatsi, B. K. (2002), "Hydrochemistry of Groundwater in the Mining Area of TarwaPrestea, Ghana", PhD. thesis, University of Ghana, pp. 70-85.

Kuma, J. S. and Younger, P. L. (2001), "Pedological characteristics related to groundwater occurrence in the Tarkwa area, Ghana", Journal of African Earth Sciences, 33 (2), pp. 363-376.

Kuma, J.S. and Ewusi, A. (2010), "Water resources issues in Tarkwa municipality, southwest Ghana", Ghana Mining Journal, Vol. 11, pp. 37 $-46$.

Lloyd, J. W. and Heathcote, J. A. (1985), Natural Inorganic Hydrochemistry in Relation to Groundwater: An Introduction, Clarendon Press, $296 \mathrm{pp}$.

Merkel, B., Planer-Friedrich, B. and Nordstrom, D. K. (2005), "Groundwater geochemistry. A practical guide to modeling of natural and contaminated aquatic systems", Berlin: Springer, 22 pp.

Smedley, P. L. (1996), "Arsenic in rural groundwater in Ghana", Journal of African Earth Sciences, 22 (4), pp. 459-470.

Yankey, R. K., Akiti, T. T., Osae, S., Fianko, J. R., Duncan, A. E. and Amartey, E. O. (2011), "The Hydrochemical Characteristics of Groundwater in the Tarkwa Mining Area, Ghana", Research Journal of Environmental and Earth Sciences, 3(5): pp. 600-607. 


\section{Authors}

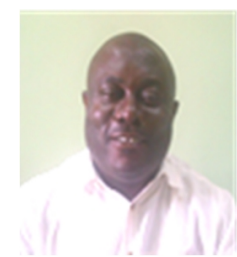

A. Ewusi holds a $\mathrm{PhD}$ Hydrogeophysics and an MSc in Environmental Hydrogeology from the Brandenburg University of Technology, Germany. He obtained a BSc (Hons) Geological Engineering from the Kwame Nkrumah University of Science and Technology (KNUST), Kumasi, Ghana. He Lectures in Geophysics and Hydrogeology. His research interests are in groundwater management and geophysics.

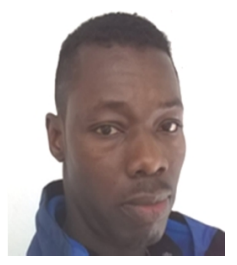

B. Y. Apeani is an MSc student at the Faculty of Geoscience, Geoengineering and Mining at the Technische Universitat, Bergakademie Freiberg, Germany. His areas of interest includes groundwater quality analysis and groundwater modelling using GIS.

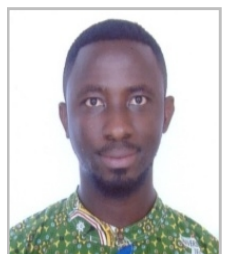

and protection.

I. Ahenkorah holds BSc in Geological Engineering from the University of Mines and Technology (UMaT), Tarkwa, Ghana. His areas of research include groundwater resources management and protection, hydrogeology and geophysics, GIS and integrated software application in groundwater resources management

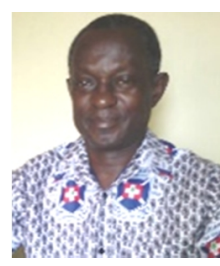

R. S. Nartey holds a Master's degree in Geology from New Mexico Institute of Mining and Technology, USA. He is currently a Senior Lecturer and the Head of the Applied Science Department at Radford University College, Accra, Ghana. His research interests are in Environmental and Economic Geology. 